\title{
Honouring the pioneers of ProPent (2000-2020): Eckart Otto and Jurie Le Roux
}

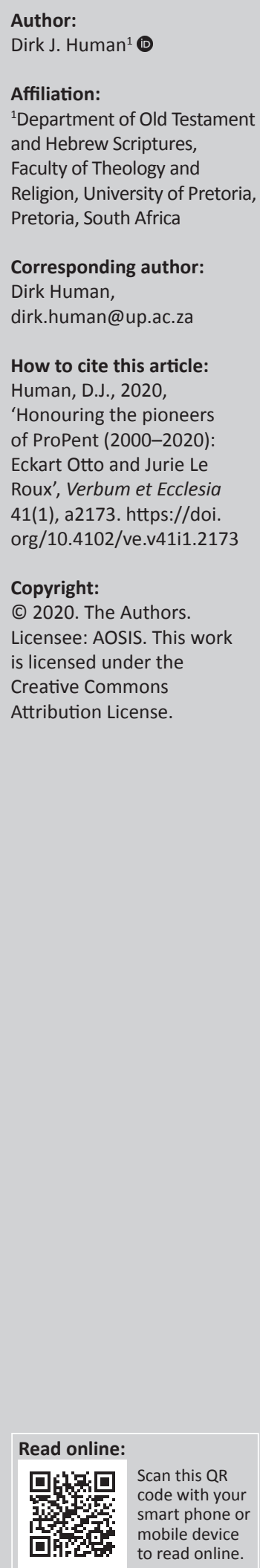

In 2021, the ProPent (Project for the Study of the Pentateuch [Projek vir die studie van die Pentateug]) seminar is going to celabrate its 20th jubilee. This event of the Department of Old Testament and Hebrew Scriptures at the Faculty of Theology and Religion, University of Pretoria, marks a special occasion on its academic calender. It is the longest existing, single academic project at the Faculty of Theology since its inception in 1917. This project has gained national and internationa academic status amongst Old Testament scholars during this period.

In August 2000 ProPent was established as a joint project between the University of Pretoria (UP) and the Ludwig Maximilian University (LMU) of Munich (Germany). As an acdemic programme it aims at promoting Pentateuch research. Therefore, the annual conference has become a landmark on the academic calender of UP and global international scholars during the first weekend in September.

Professor Eckart Otto, emeritus of the LMU and honorary doctor at UP, together with Prof. Jurie Le Roux, initiated this project. They are indeed the pioneers who established and sustained the project with various add-on academic stimuli and benefits for Old Testament Studies globally. Till 2019 they have both been responsible for the organising of ProPent, which assembles each year. The 20th anniversary, which was supposed to be celebrated in 2020, was postponed till 2021 because of the globally affected coronavirus disease 2019 (COVID-19) pandemic. Although Otto and Le Roux already retired, they have still continued to drive this programme.

During its 20 year existence, ProPent has emerged as an international study group on the Pentateuch. Apart from many national and international Pentateuch scholars, renowned international academics have participated. Over the years they included Jan Waggenaar (Utrecht, Netherlands), John van Seters (North Carolina, USA), Georg Braulik (Vienna, Austria), Frank-Lothar Hossfeld (Bonn, Germany), Hans Ausloos (Lovain, Belgium), Georg Fischer (Innsbruck, Austria), Ulrich Berges (Bonn, Germany), Simone Paganini (Aachen, Germany), Dominik Markl (Rome, Italy), Christiaan Frevel (Bochum, Germany), Thomas Römer (Lausanne, Switzerland; Paris, France), Raik Heckl (Leipzig, Germany), Steven McKenzie (Memphis, Texas, USA) and Catherina Pyschne (Berlin, Germany). Various colleagues from several South Afican institutions participated over these two decades.

In 2004 and 2007 ProPent meetings were held at the LMU, Munich. In addition, ProPent was allotted a morning session at the International Society of Biblical Literature's (SBL) meeting at Vienna (2007). In 2013 ProPent had sessions at the International Organisation for the Study of the Old Testament (IOSOT) in Munich, whilst in 2016 sessions were allotted at the IOSOT conference in Stellenbosch. Information about the ProPent meetings since 2006 is available at https://up-za.academia.edu/JurieLeRoux. It contains information about the speakers, the themes discussed, the programmes and abstracts of all the papers read.

Eckart Otto is a world-class Pentateuch scholar in his own right. He is a Deuteronomy and Max Weber specialist, who is also a subject specialist in ancient Near Eastern legal texts and Greek philosophy. Otto wrote a monumental commentary on Deuteronomy in the HThKAT series. Jurie Le Roux has for many years driven Pentateuch Studies in South Africa. With his 'historical mind' and diachronic approach he has brought scholars and students of the Pentateuch in South Africa together and incited the paradigmn shift from an only-synchronical approach to a diachronic-determined-synchrony approach.

ProPent has indeed become an important theological incubator where South African and international scholars meet and discuss matters related to the Pentateuch in particular and the Old Testament in general. It also heralded the beginnings of a fresh start in South African 
Pentateuchal studies. The term 'fresh' is used deliberately because except for a few past attempts the critical investigation of the Pentateuch never came to fruition in South Africa. The ProPent project has filled this gap.

This humble Festschrift intends to pay tribute to the work done by Eckart Otto and Jurie Le Roux for their pionering commitment over two decades to Pentateuch Studies. They are indeed the pioneers of the ProPent idea. The South African and international scholarly community honour them for this contribution. In this regard, their names are engraved on the monument of Old Testament and Pentateuch Studies.

Two colleagues each describe the scholarly contribution of Eckart Otto (J.H. Le Roux and T. Römer) and Jurie Le Roux
(E. Scheffler and C. Lombaard). All other articles are dedicated to both these pioneers of ProPent. Some have already appeared in Verbum et Ecclesia.

I also wish to thank the Editor-in-Chief of Verbum et Ecclesia, Prof. Danie Veldsman, for his gracious logistical and financial support to print this volume.

\section{Acknowledgements Competing interests}

The author has declared that no competing interests exist.

\section{Author's contributions}

I declare that I am the sole author of this research article. 